\title{
Influence of Cold Maceration Time on Chromatic and Microbio- logical Characteristics of Cabernet Sauvignon Wines
}

\author{
B. Kuchen ${ }^{1,2 *}$, F. Vazquez ${ }^{1}$, M.V. Mestre ${ }^{1,2}$, M.E. Toro ${ }^{1}$, Y.P. Maturano ${ }^{1,2}$
}

(1) Instituto de Biotecnología, Universidad Nacional de San Juan (UNSJ), Av. San Martín 1109 (O), San Juan 5400, Argentina

(2) Consejo Nacional de Investigaciones Científicas y Tecnológicas (CONICET), Godoy Cruz 2290 Ciudad Autónoma de Buenos Aires C1425FQB, Argentina

Submitted for publication: June 2017

Accepted for publication: October 2017

Keywords: Pre-fermentative cold soak, colour parameters, maceration time, yeast populations, wine

The pre-fermentative cold soak (CS) is proposed so as to extract and stabilise polyphenolic compounds in wines. CS is applied empirically to Cabernet Sauvignon in Cuyo, Argentina; however, there is poor scientific background on this technique. The aim was analyse the effect of cold soak time on colour parameters such as total polyphenols, total anthocyanins, tannins, colour and polymerisation indexes. Moreover, Saccharomyces and non-Saccharomyces populations were studied to evaluate their impact on colour. Cabernet Sauvignon must (Pedernal, San Juan) was distributed into four vessels: CONTROL (CT): simultaneous maceration and alcoholic fermentation (AF) with commercial yeast D254; T1: CS for two days; T2: CS for five days; and T3: CS for seven days. T1, T2 and T3 were maintained at $4 \pm 1^{\circ} \mathrm{C}$ during CS. They were later inoculated with D254 (AF: $\left.22 \pm 1^{\circ} \mathrm{C}\right)$. The total polyphenol index (TPI), total anthocyanins (TA) and tannins were quantified during CS and AF. The colour index (CI) and polymerisation index (PI) were determined at the end of AF. The total yeast populations of Saccharomyces and non-Saccharomyces were quantified during CS and AF. The highest values of TA, tannins, TPI and PI were obtained by CT. This treatment also registered the highest total yeast population and the highest total yeast death. The highest CI was observed in T3. When Saccharomyces was found at the end of CS (T1 and T2), it dominated the alcoholic fermentation in the early stages (not observed in CT and T3). The use of the pre-fermentative CS technique in Cabernet Sauvignon wines is promising for young wines due to the increased colour obtained.

\section{INTRODUCTION}

Phenolic compounds (e.g. anthocyanins, tannins) are responsible for wine colour and flavour characteristics (Ribéreau-Gayon, 2006). Their presence in wine depends on several factors, such as grape variety, maturity, climate and vinification techniques (González-San José et al., 1990; González-Neves et al., 2012). The colour of red wines, an important quality factor, is primarily dependent on anthocyanins and their concentration, and metabolites that are accumulated in the grape skin (Mangani et al., 2011; González-Neves et al., 2012). Despite this, there is no direct relationship between anthocyanin concentration and wine colour (Cheynier et al., 2006). Ribéreau-Gayon (1982) did research on anthocyanin extraction and the time of traditional maceration and found than these increase to a maximum during the first five or six days of maceration. Different conditions affect anthocyanins and wine colour, such as pH (Somers \& Evans, 1974; Brouillard, 1982; Cheynier et al., 2006; Kammerer, 2016), dose of $\mathrm{SO}_{2}$ (Casassa, 2007;
Kammerer, 2016), copigmentation of anthocyanins (Boulton, 2001; Casassa, 2007; Cavalcanti et al., 2011; Benito et al., 2017), anthocyanin-derived pigments (Morata et al., 2003; Jackson, 2014; Benito et al., 2017), and anthocyanin and tannin polymerisation (Ribéreau-Gayon, 1982; Jackson, 2014).

For a few decades, techniques have been studied to extract higher polyphenol concentrations and improve the final colour of wines (Marais, 2003). Cold soaking (CS), also known as pre-fermentative cold maceration or cryomaceration, is one of them. This technique consists of maintaining crushed grapes at low temperatures $\left(0^{\circ} \mathrm{C}\right.$ to $15^{\circ} \mathrm{C}$ ) (Reynolds et al., 2001; Marais, 2003; De Beer et al., 2017) for a variable time period (from a few hours to one to two weeks) (Gómez-Míguez et al., 2007; Heredia et al., 2010). The beginning of the fermentation process is therefore delayed (Heredia et al., 2010). The purpose of CS is to increase the extraction and stabilisation of the polyphenolic

*Corresponding author: Email address: bekuchen@hotmail.com [Tel.: +542644211700)

Acknowledgments: This work was supported by CICITCA-UNSJ and PAE-PICT-2007-02359. The authors would also like to thank engineer Hebe Norte and oenologist Franco Landa from the National Viticulture Institute (INV), for their assistance with colour determinations, as well as Graffigna winery (Pernod Ricard Argentina), for providing the grape must 
compounds (anthocyanins and tannins with low molecular weight) in the liquid phase and to make the extraction during the fermentative process as short as possible to avoid the extraction of bitter tannins from the seeds that is increased by the presence of ethanol (Álvarez et al., 2006). Previous studies suggest that an increase in the duration of CS must be studied with the purpose of increasing polyphenol extraction (Marais, 2003; Casassa, 2007). On the other hand, when the maximum extraction is reached, the processes of dissolution and diffusion stop (Boulton, 2001), or it is even re-adsorbed, and the risk of large-size populations of contaminant yeasts increases. There are several CS studies in which time is a variable: one day (De Beer et al., 2006), two days (De Beer et al., 2006), six days (Zou et al., 2002), seven days (Casassa et al., 2007), and up to 10 days (Reynolds et al., 2001). Also, due to the facilitation of anthocyanin extraction and the availability of copigments at the start of vinification, copigmentation would be favoured and could be responsible for the intensification of colour (Cavalcanti et al., 2011; Casassa et al., 2015). The colour intensification generated by copigmentation could be between two and six times higher (Boulton, 2001; Casassa, 2007; Baiano et al., 2015) in respect to the anthocyanins without copigments.

The main variables affecting pre-fermentative cold soak, such as temperature and the time extension, have a direct impact on the yeasts involved in the fermentation process. The CS technique is critical to the quantitative and qualitative microbiological composition of the must during the prefermentative phase (Hierro et al., 2006; Albertin et al., 2014; Maturano et al., 2015). The natural bio-selective effect exerted by ethanol is absent; moreover, low temperatures during a certain time favour the development of cryotolerant yeast populations that could affect the performance of the subsequent alcoholic fermentation (Hierro et al., 2006; Mendoza et al., 2009). Low temperatures have been shown to modify the conditions of competition between Saccharomyces and non-Saccharomyces yeasts, e.g. modifying the permeability of the membrane. (Fleet 2003, Fugelsang and Edwards 2006). The development of some non-Saccharomyces yeasts could cause a scarcity of some essential nutrients for $S$. cerevisiae in the medium (Maturano et al., 2015), and this may be attributed to the fructophilic or glycophilic nature of these non-Saccharomyces yeasts (Granchi et al., 2002). Even the inhibition of $S$. cerevisiae by non-Saccharomyces species is mediated by the release of acetaldehyde and acetic acid (Mortimer, 2000; Mendoza et al., 2007) or killer toxins (Liu et al., 2013).

Both Saccharomyces and non-Saccharomyces yeasts can produce enzymes of oenological interest, such as cellulases, xylanases, pectinases and $\beta$-glucosidases (Fleet, 2003; Maturano et al., 2012). Therefore yeast could have a positive influence on wine colour, enhancing phenolic compound extraction by cell wall-degrading enzymes (Charoenchai et al., 1997; Fernández et al., 2000; Strauss et al., 2001; Maturano et al., 2012), forming new derived pigments due to the release of acetaldehyde, pyruvate or vinylphenols (Asenstorfer et al., 2003; Morata et al., 2003; Eglinton et al., 2004; Jackson, 2014), and increasing the stability of the wine colour, including ethanal bonds between anthocyanins and tannins (Chalier et al., 2007; Domizio et al., 2014).
Nevertheless, yeasts could have a negatively effect on colour, degrading anthocyanins by $\beta$-glucosidase activity (Mateo \& Di Stefano, 1997; Manzanares et al., 2000; Vernocchi et al., 2015) and/or by them being absorbed by the cell walls (Morata et al., 2003, 2016).

The cold soaking technique is used in Argentina for the third-most planted cultivar in the country, Cabernet Sauvignon (Instituto Nacional de Vitivinicultura, I.N.V.: http://www.inv. gov.ar), although without conscious evaluation of its effect on organoleptic or colour properties. Not much scientific background was found for this technique in its application in Merlot and Malbec regional wines (Casassa, 2007; Casassa et al., 2007), and in regional Cabernet Sauvignon (Maturano et al., 2015). This cultivar has achieved great success as a new world and old world wine (Robinson, 2006). The Argentinian Cabernet Sauvignon is probably originally the Chilean one, introduced by Don Silvestre Ochagavia in 1851 (Pelsy, 2010), and it is relevant to study this varietal because of its regional application.

The aim of this work therefore was to investigate the effect of duration of cold soak on colour parameters such as anthocyanins and related molecules, stable colour and the colour index in a Cabernet Sauvignon wine, to study the proportions of Saccharomyces and non-Saccharomyces yeast populations during cold soak and alcoholic fermentation, and to analyse the effect of yeasts on colour.

\section{MATERIALS AND METHODS}

\section{Grape must, fermentations and sampling}

Grapes of Vitis vinifera cv. Cabernet Sauvignon (Pedernal, San Juan) were harvested by hand from vineyards located in Pedernal (lat. 31 $59^{\prime} \mathrm{S}$, long. 68 $44^{\prime} \mathrm{W}, 1043$ meters above sea level), San Juan, Argentina, between 19:00 and 20:00 on 2012-04-20. The grapes were at $24^{\circ}$ Brix (handheld refractometer), with a $\mathrm{pH}$ of $3.8\left(\mathrm{Adwa}^{\circledR}-\mathrm{AD} 8000\right)$ and good sanitary conditions. They were processed after half an hour using a horizontal destemmer (Delta $\left.{ }^{\circledR}\right)$. Grape must was distributed among 12 sterile glass containers (20 L capacity), containing $14 \mathrm{~L}$ each (three replicates per treatment: $n=3)$, and placed in a refrigerating chamber $\left(4 \pm 0.5^{\circ} \mathrm{C}\right)$. The experimental design was completely randomised. During vatting, $\mathrm{SO}_{2}(50 \mathrm{mg} / \mathrm{L})$ was added (the initial grape must sample was previously taken out) and homogenised.

Treatments were performed in the following way: Treatment 1 (T1), Treatment 2 (T2) and Treatment 3 (T3) were executed with pre-fermentative cold soak (CS) at $4 \pm 0.5^{\circ} \mathrm{C}$ in a refrigerating chamber, for two, five and seven days respectively. At the end of each pre-fermentative $\mathrm{CS}$ period and prior to yeast inoculation, the musts were warmed up to $22 \pm 1{ }^{\circ} \mathrm{C}$. Later, the vessels were inoculated with $0.3 \mathrm{~g} / \mathrm{L}\left(2 \times 10^{6}\right.$ cells $\left./ \mathrm{mL}\right)$ of the commercial active dry yeast, Saccharomyces cerevisiae Lalvin D254 (Lallemand Inc., Montreal, Canada). Alcoholic fermentation (AF) was performed at $22 \pm 1{ }^{\circ} \mathrm{C}$, with one daily manual shake. A control treatment (CT) was included, which consisted of the inoculation of the same fresh must (without CS) with $S$. cerevisiae D254 and simultaneous maceration and AF under the same conditions as those of the CS treatments.

Samples were taken on day 0 (Initial must), during CS on day 1 and 2 for treatment 1, on day 1,2 and 5 for treatment 
2, and on day 1, 2, 5 and 7 for treatment 3; and during the initial, middle ( 1040 to $\left.1050^{\circ} \mathrm{Be}\right)$ and final alcoholic fermentation $\left(990\right.$ to $\left.995^{\circ} \mathrm{Be}\right)$. AF was controlled by density in ${ }^{\circ}$ Baumè, measured by a densimeter, and by measurements of temperature and residual reducing sugar (Miller, 1959).

Ethanol, $\mathrm{pH}$, titratable and volatile acidity, and dry extract and glycerol contents were obtained using a FOSS WineScan (FT-120) rapid-scanning infrared Fouriertransform spectrometer with WineScan software Version 2.2.1 (FOSS, Hillerød, Denmark). Residual reducing sugars were determined following the official reference method (O.I.V., 1990) and free and total $\mathrm{SO}_{2}$ levels were determined using the aspiration method (Iland et al., 2004).

\section{Spectrophotometric analysis}

The total polyphenol index was determined as describes by Ribéreau-Gayon (1998), with modifications, by direct reading of the absorbance of the samples (1:50 dilution) at $280 \mathrm{~nm}$ and then multiplying the result by 50 . Total anthocyanins were measured by diluting the sample $(1: 20)$ with $1 \% \mathrm{p} / \mathrm{v}$ hydrochloric acid $(0.1 \mathrm{M})$. Spectrophotometric readings of single treated aliquots at $520 \mathrm{~nm}$ were then compared by interpolating with a curve of known concentration of malvidin-3-glucoside (Cadot et al., 2011). Tannins were estimated through total phenols and total anthocyanins (Kennedy et al., 2006). The polymerisation index was determined by diluting the sample $(1: 10)$ in a buffer (model wine, $0.5 \% \mathrm{w} / \mathrm{v}$ tartaric acid in $12 \% \mathrm{v} / \mathrm{v}$ ethanol adjusted to $\mathrm{pH} 3.4$ and $5 \mathrm{M} \mathrm{NaOH}$ ) and $0.375 \% \mathrm{w} / \mathrm{v}$ sodium metabisulphite, after which the absorbance was read at $520 \mathrm{~nm}$ (Somers \& Evans, 1974, 1977). The percentage of polyphenol extraction was calculated with reference to the maximum extracted. The colour index was calculated by the protocols of Sudraud (1958), and as found on the website of the Instituto Nacional de Vitivinicultura (I.N.V.) (n.d.).

\section{Total yeast population}

Decimal dilutions $(0.1 \mathrm{~mL})$ were plated onto Wallerstein Laboratory (WL) nutrient agar medium (Oxoid, Hampshire,
UK), supplemented with $0.2 \mathrm{~g} / \mathrm{L}$ dichloran (Fluka A.G., St. Gallen, Switzerland) and $0.5 \mathrm{~g} / \mathrm{L}$ chloramphenicol (Sigma Aldrich, Saint Louis MO, United States) to inhibit moulds and bacteria respectively. Petri dishes were incubated at $25^{\circ} \mathrm{C}$ for five days. The colonies were counted (total viable yeasts) and the results were expressed in colony-forming units per $\mathrm{mL}(\mathrm{cfu} / \mathrm{mL})$. Each colony was plated on lysine agar, which inhibits Saccharomyces, to distinguish between Saccharomyces and non-Saccharomyces yeasts (Fowell, 1965; Kurtzman et al., 2011).

\section{Data analysis}

Each analysis was done independently and the results were presented as the means of three determinations with the corresponding standard deviation $( \pm \mathrm{SD})$. The Infostat/ Professional version 1.5 (Estadística y Diseño, FCA, Universidad Nacional de Córdoba, Córdoba, Argentina) was used for data analysis. The chemical and chromatic effects of the winemaking treatments were evaluated by one-way analysis of variance (ANOVA) with a 5\% level for rejection of the null hypothesis. Tukey's honestly significant difference (HSD) test was used as a post hoc comparison of means.

\section{RESULTS}

\section{Standard wine parameters}

The Control Treatment (CT) and Treatment 1 (T1) wines registered higher glycerol and higher titratable acidity compared with Treatment 2 (T2) and Treatment 3 (T3), while the latter contained higher residual sugars and higher dry extract (Table 1). The volatile acidity of CT was significantly lower than that registered in the CS treatments; nevertheless, all treatments were below the established legal limit (1.2 \pm $0.20 \mathrm{~g} / \mathrm{L}$ ) (acetic acid), as found on the INV website.

Colour analysis during cold soak and alcoholic fermentation

Total polyphenol index (TPI)

Cold soaking (CS): Fifty-nine percent of total polyphenols were extracted during the CS in Treatment 1 (35.3 \pm 1.2$)$, and

TABLE 1

Physicochemical properties of wines obtained at different durations of CS at $4{ }^{\circ} \mathrm{C}$ and in the control.

\begin{tabular}{lllll}
\hline Analysis & CT & T1 & T2 & T3 \\
Ethanol $(\% \mathrm{v} / \mathrm{v})$ & $15.73 \pm 0.04 \mathrm{a}$ & $15.53 \pm 0.06 \mathrm{a}$ & $15.21 \pm 0.07 \mathrm{a}$ & $15.04 \pm 0.11 \mathrm{a}$ \\
$\mathrm{pH}$ & $3.89 \pm 0.01 \mathrm{a}$ & $3.86 \pm 0.01 \mathrm{a}$ & $3.88 \pm 0.01 \mathrm{a}$ & $3,86 \pm 0,02 \mathrm{a}$ \\
Volatile acidity $(\mathrm{g} / \mathrm{L})$ & $0.25 \pm 0.01 \mathrm{a}$ & $0.32 \pm 0.01 \mathrm{~b}$ & $0.33 \pm 0.01 \mathrm{~b}$ & $0.31 \pm 0.01 \mathrm{~b}$ \\
Titratable acidity $(\mathrm{g} / \mathrm{L})$ & $7.02 \pm 0.03 \mathrm{~b}$ & $6.95 \pm 0.03 \mathrm{~b}$ & $6.27 \pm 0.08 \mathrm{a}$ & $6.46 \pm 0.03 \mathrm{a}$ \\
Density $(\mathrm{g} / \mathrm{mL})$ & $0.99 \pm 0.01 \mathrm{a}$ & $0.99 \pm 0.01 \mathrm{a}$ & $0.99 \pm 0.01 \mathrm{a}$ & $0.99 \pm 0.01 \mathrm{a}$ \\
Glycerol $(\mathrm{g} / \mathrm{L})$ & $8.01 \pm 0.19 \mathrm{~b}$ & $7.46 \pm 0.03 \mathrm{~b}$ & $6.28 \pm 0.12 \mathrm{a}$ & $6.51 \pm 0.05 \mathrm{a}$ \\
Residual sugars $(\mathrm{g} / \mathrm{L})$ & $2.04 \pm 0.49 \mathrm{a}$ & $2.37 \pm 0.45 \mathrm{a}$ & $3.67 \pm 0.35 \mathrm{~b}$ & $3.90 \pm 0.03 \mathrm{~b}$ \\
Free $\mathrm{SO}_{2}(\mathrm{mg} / \mathrm{L})$ & $9.00 \pm 6.01 \mathrm{a}$ & $3.50 \pm 0.50 \mathrm{a}$ & $7.50 \pm 1.50 \mathrm{a}$ & $9.00 \pm 0.01 \mathrm{a}$ \\
Total $\mathrm{SO}_{2}(\mathrm{mg} / \mathrm{L})$ & $51.50 \pm 3.50 \mathrm{a}$ & $26.50 \pm 2.50 \mathrm{a}$ & $42.00 \pm 9.01 \mathrm{a}$ & $52.50 \pm 1.50 \mathrm{a}$ \\
Dry extract $(\mathrm{g} / \mathrm{L})$ & $36.67 \pm 1.83 \mathrm{a}$ & $38.63 \pm 0.05 \mathrm{a}$ & $44.1 \pm 0.84 \mathrm{~b}$ & $46.09 \pm 1.75 \mathrm{~b}$ \\
\hline
\end{tabular}

* Means followed by standard deviation $(\mathrm{n}=3)$. CT: Control Treatment, T1: Treatment 1, T2: Treatment 2, T3: Treatment 3. ${ }^{\text {a-b-c }}$ Values with different letters in same line are significantly different at the $\mathrm{p}<0.05$ level according to Tukey's test. 
$66 \%$ and $71 \%$ were extracted during the CS of Treatment 2 and Treatment 3 respectively (T2: $36.45 \pm 1.9$; T3: $40.2 \pm$ 2.3) (Fig. 1).

Alcoholic fermentation (AF): An extraction curve of polyphenols with a high rate at the beginning and a lower rate as the experiment progresses was described by CT, T1 and T2. Despite a decrease in the total polyphenol index registered at the beginning of AF by CT (Fig. 1), further measurements showed a progressive increase in this treatment, significantly exceeding the rest of the treatments (TPI: $71.15 \pm 2.3$ ). At the end of AF, the CS treatments (T1, T2 and T3) reached values between $55.45 \pm 2.7$ and $56.75 \pm 2.8$; there were not significant differences among them. It is remarkable that $\mathrm{T} 3$ presented an increase after the middle of AF.

\section{Total anthocyanins (TA)}

Cold soaking: A total of $75.16 \pm 0.2 \%$ of TA was extracted during the CS period by T1, T2 and T3, describing an extraction curve with a high initial rate and a decreasing rate during the process, reaching a maximum of nearly $1.2 \mathrm{~g} / \mathrm{L}$ of total anthocyanins (at a maximum on the fifth day of maceration). Also, after the fifth day of CS, a loss of TA (6.77\%) was shown by T3 (Fig. 2).

Alcoholic fermentation (AF): At the beginning of $\mathrm{AF}$, a decrease in TA was registered in CT, T1 and T2. Later, up until the middle of alcoholic fermentation, a vigorous extraction of TA was shown by $\mathrm{CT}$ and $\mathrm{T} 1$, reaching the highest values $(1.915 \pm 0.08 \mathrm{~g} / \mathrm{L})$ of the present work (Fig. 2). Nevertheless, after the middle of AF, an important decrease in TA was registered. Despite this behaviour, the highest total anthocyanins extracted $(1.69 \pm 0.09 \mathrm{~g} / \mathrm{L})$ was registered by the control at the end of AF, followed by Treatment 1 . Treatment 3 showed a slight extraction of total anthocyanins with respect to the rest of treatments, until the middle of alcoholic fermentation, when the extraction rate increased, reaching $1.46 \pm 0.08 \mathrm{~g} / \mathrm{L}$ at the end of $\mathrm{AF}$. However, Treatment 3 registered the lowest extraction of TA - significantly lower than that of the control (Fig. 2).

\section{Tannins}

Cold soaking: At the beginning of this period, on the first day, a slight loss of tannins was registered by all CS treatments. These then showed a constant increase until the end of CS (Fig. 3). Moreover, from the $5^{\text {th }}$ to the $7^{\text {th }}$ day, a $40 \%$ increase in total tannin content was shown by $\mathrm{T} 3$ in comparison to that of the initial must.

Alcoholic fermentation: The highest extraction rate at the beginning of $\mathrm{AF}$ and from the middle to the end of alcoholic fermentation was shown by the control treatment, reaching the highest tannin concentration reported in this work (1.87 $\pm 0.07 \mathrm{~g} / \mathrm{L})$. Treatment 3 reported an initial loss of tannins, although the tendency changed later, as well as that of the control. Therefore, the tannin extraction increased from the middle to the end of AF, obtaining higher values with significant differences between $\mathrm{CT}$ and $\mathrm{T} 3$, and with respect to $\mathrm{T} 1$ and $\mathrm{T} 2$. The $\mathrm{T} 3$ results in this work show that the cold soak treatment extracted more tannins (Fig. 3).

\section{Wine colour}

The highest polymerisation index (PI) (pigments stable to $\mathrm{SO}_{2}$ bleaching) was quantified in the CT $(2.73 \pm 0.01)$ (Fig. 1). Moreover, the highest TA and tannins (both previously described) were registered in the CT (Fig. 2). Nevertheless, is important to highlight that this treatment obtained a significantly lower colour index than T3 and T1 $(\mathrm{CI}=1457 \pm 10)$ (Fig. 4). The highest CI in this assay was registered by Treatment 3 , which reached $1522 \pm 6$, in spite

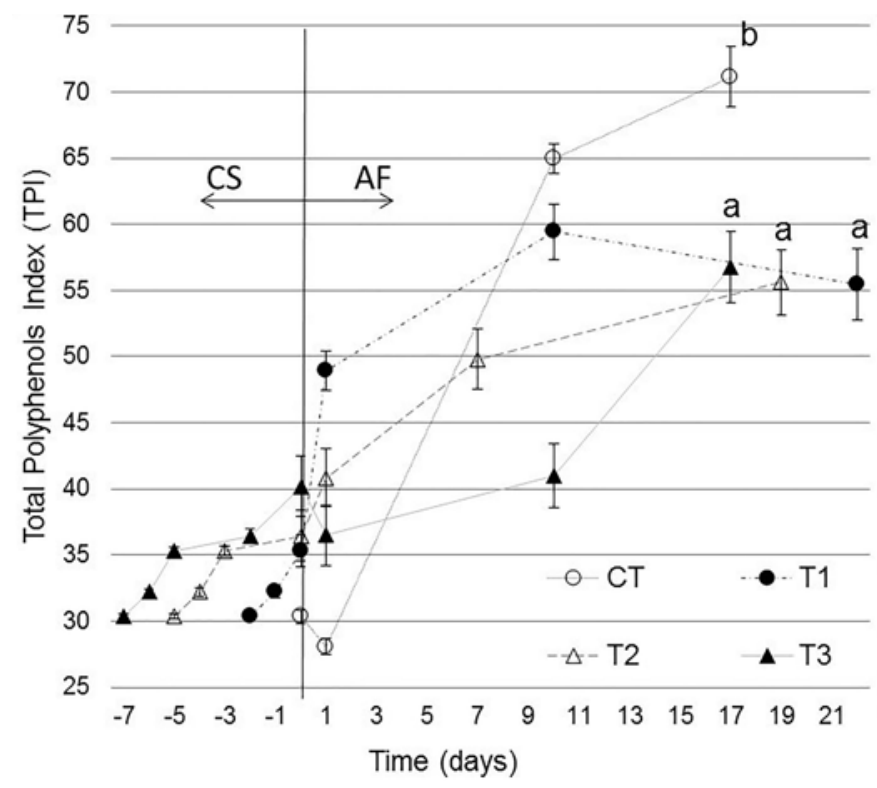

FIGURE 1

Total polyphenol index during cold soaking (CS) and alcoholic fermentation (AF). CT: Control Treatment, T1: Treatment 1, T2: Treatment 2, T3: Treatment 3. Different letters are significantly different $(\mathrm{p}<0.05)$ between treatments. 


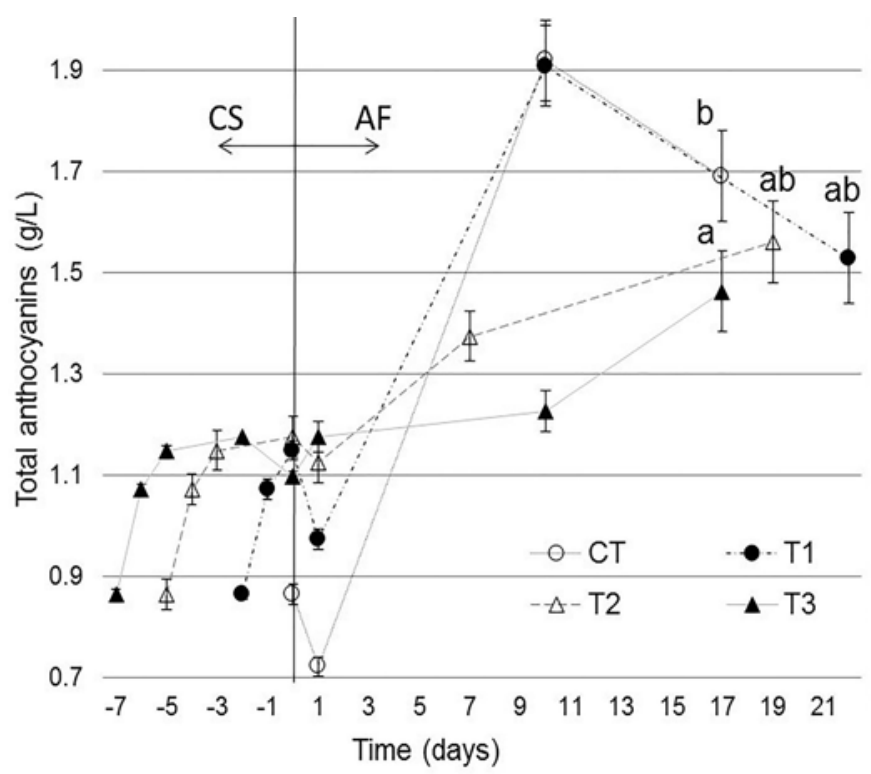

FIGURE 2

Total anthocyanins during cold soaking (CS) and alcoholic fermentation (AF). CT: Control Treatment, T1: Treatment 1, T2: Treatment 2, T3: Treatment 3. Different letters are significantly different $(\mathrm{p}<0.05)$ between treatments.

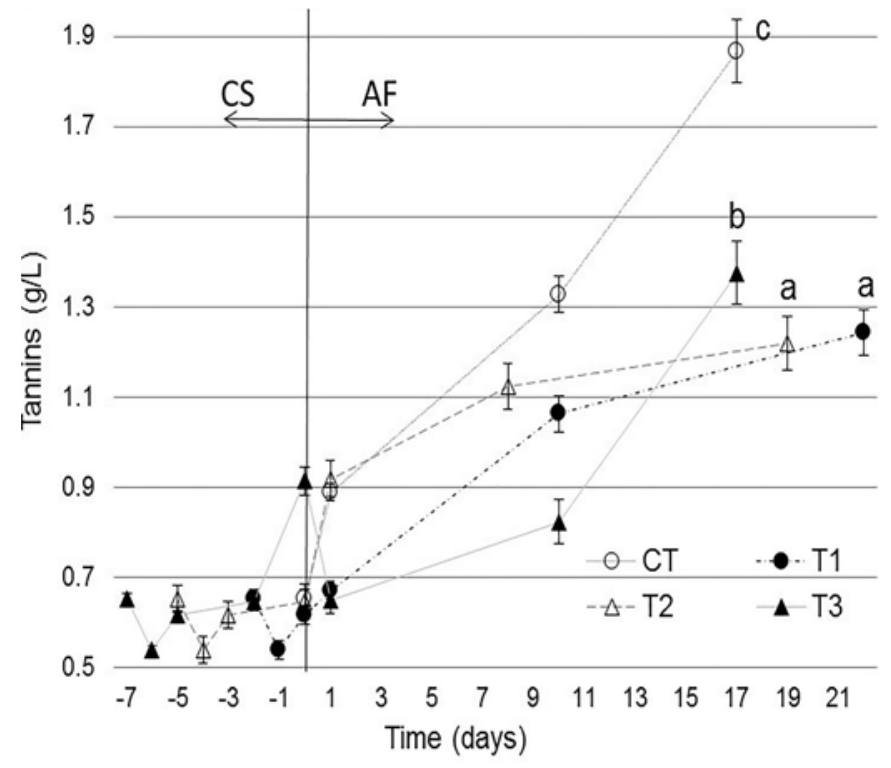

FIGURE 3

Tannins during cold soaking (CS) and alcoholic fermentation (AF). CT: Control Treatment, T1: Treatment 1, T2: Treatment 2, T3: Treatment 3. Different letters are significantly different $(\mathrm{p}<0.05)$ between treatments.

of the low total anthocyanin concentration of these wines (TA: $1.46 \pm 0.08 \mathrm{~g} / \mathrm{L}$ ) compared to the rest of treatments (Fig. 4). Moreover, T3 reached a polymerisation index that was significantly lower than that of CT.

\section{Yeast populations}

\section{Total yeast population}

On the first day of the cold soak (CS) period, the CS treatments registered an average of $53 \%$ of the increase in the total yeast populations (TYP) with respect to must that had just been crushed (Fig. 5B, C and D). A decrease was registered on the second day, when similar values to that from the must were obtained. On the fifth day of CS, Treatments 2 and 3 suffered a decrease of $20 \%$ in the TYP in comparison with the second day (Figure 5C and D). In the case of Treatment 3 , TYP increased by $450 \%$ with respect to the fifth day of the final pre-fermentative stage (Figure 5D). During alcoholic fermentation, the highest cell total population in the middle of $\mathrm{AF}(1.73 \mathrm{E}+07 \mathrm{cfu} / \mathrm{mL})$ and a low cell population at the end of $\mathrm{AF}(1.45 \mathrm{E}+06 \mathrm{cfu} / \mathrm{mL})$ were registered by the control treatment (Figure 5A). The lowest population in the middle of $\mathrm{AF}(9 \mathrm{E}+06 \mathrm{cfu} / \mathrm{mL})$ and the lowest cell population at the end of AF $(1.33 \mathrm{E}+06 \mathrm{cfu} / \mathrm{mL})$ were obtained in Treatment 3 (Figure $5 \mathrm{~A}$ to $\mathrm{D}$ ). 


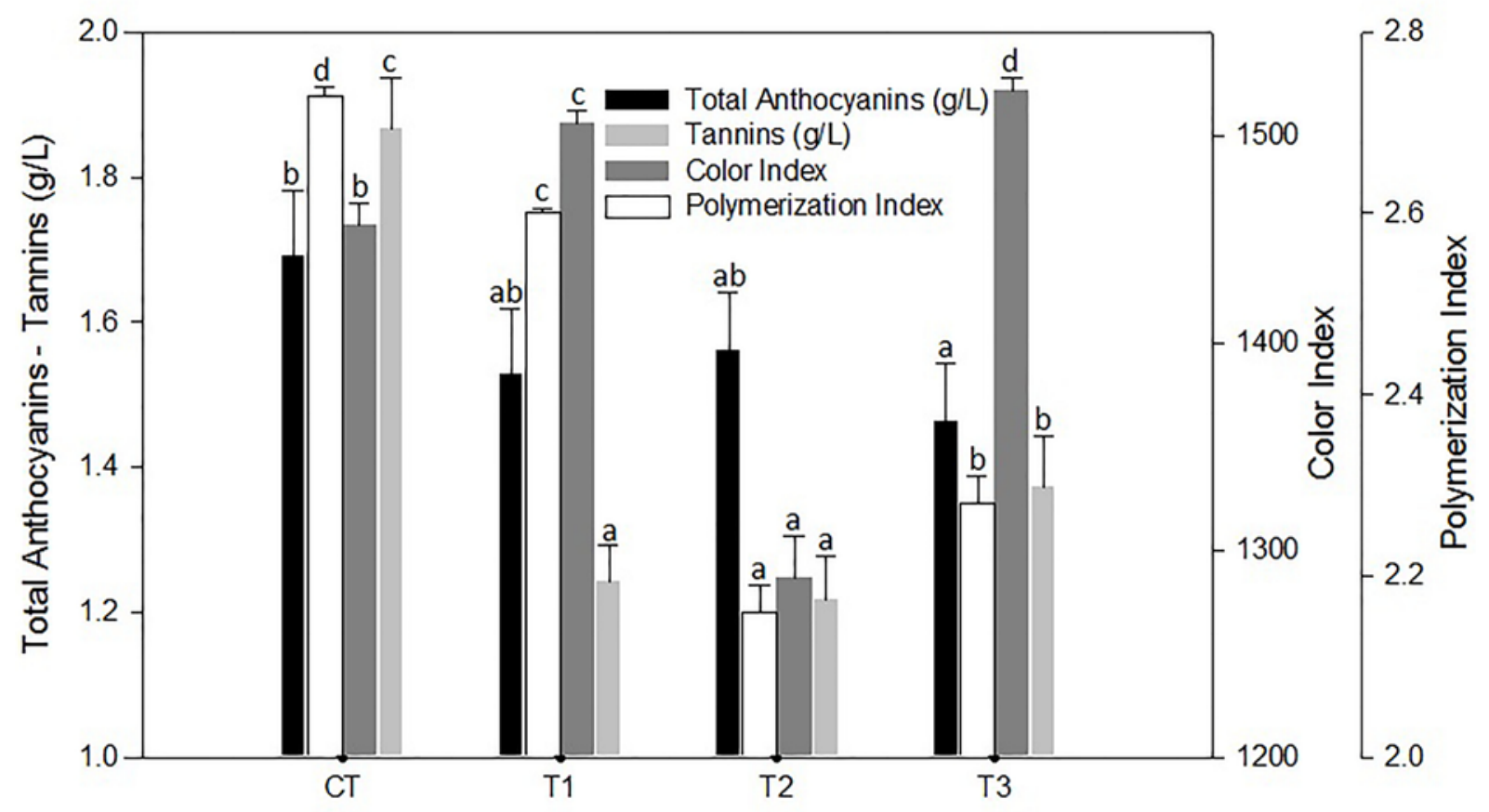

FIGURE 4

Colour index, polymerisation index, total anthocyanins $(\mathrm{g} / \mathrm{L})$ and tannins $(\mathrm{g} / \mathrm{L})$ at the end of fermentation. CT: Control Treatment, T1: Treatment 1, T2: Treatment 2, T3: Treatment 3. Different letters are significantly different $(p<0.05)$ between treatments.

\section{Saccharomyces and non-Saccharomyces populations}

Eighty-seven percent of non-Saccharomyces populations and $13 \%$ of Saccharomyces populations were found at day 0 , just after the grapes had been crushed. During the CS, non-Saccharomyces yeasts predominated in the grape must of the different treatments (more than 60\%). Moreover, the proportions of Saccharomyces and non-Saccharomyces yeasts were modified throughout the pre-fermentative stage (Fig. 5B, C and D).

Treatment 1 (Figure 5B) (two days of cold soak) showed an increase in native Saccharomyces of more than $20 \%$ during CS, compared to $37 \%$ recorded in initial must inoculated with commercial Saccharomyces before the start of AF. Treatment 2 (Fig. 5C) (five days of CS) registered fluctuations, although the proportions of native Saccharomyces before the inoculation of the commercial $S$. cerevisiae were similar to the initial proportions in the must (10\%). Finally, in Treatment 3 (Fig. 5D) (seven days of $\mathrm{CS}$ ), the non-Saccharomyces yeast dominated the must and no Saccharomyces was found at the end of CS, in spite of the variations in the populations.

During AF, after inoculation with commercial S. cerevisiae, Saccharomyces was dominant in T1 and T2 (between 90\% and 99\%) (Fig. 5B and C). T1 and T2 were the treatments in which higher proportions of $S$. cerevisiae were found during AF. Nevertheless, a different situation was observed during the same period in CT and T3 (Fig. 5A to D). High proportions of non-Saccharomyces yeasts were registered in CT and T3, predominating Saccharomyces only at the end of AF.

\section{DISCUSSION}

The extraction curve of total anthocyanins (TA) (Fig. 2) during the cold soak (CS) describes a high extraction rate at the beginning of this period and a decrease in the extraction rate as it progressed, reaching a maximum of nearly $1.2 \mathrm{~g} / \mathrm{L}$. These results are in agreement with the general physicochemical phenomenon of "saturation", which is mostly dependent on the temperature $\left(4^{\circ} \mathrm{C}\right.$ during $\left.\mathrm{CS}\right)$ and "extraction equilibrium" (hydric medium during CS). Under these stable conditions, colour molecules cannot continue flowing from the grape skins to the hydric medium beyond the equilibrium, so that the saturation level depends on their concentration inside the grapes (Boulton, 2001). The maximum reached by Treatment 3 therefore is possibly related to the equilibrium of the molecules under such conditions. Furthermore, after the fifth day of CS, a loss of TA was shown by T3, probably related to polyphenol oxidase (PPO) enzymes from the grapes. These enzymes were probably active due to the absence of vigorous fermentation and hence the presence of dissolved oxygen, transforming phenols into quinones (Casassa, 2007). It is also important to highlight the increase in total yeast population (450\%), of which non-Saccharomyces yeasts represented $100 \%$ of the yeasts. This fact could be explained by the development of cryotolerant yeast populations that would have been favoured at $4^{\circ} \mathrm{C}$ (Hierro et al., 2006; Maturano et al., 2015). The increase in the total yeast population (considering the size of the population in this treatment, $1.39 \mathrm{E}+4$ $\mathrm{cfu} / \mathrm{mL}$ ) during CS could have accelerated anthocyanin degradation by $\beta$-glycosidase enzymes due to the cleaving of the glycosidic residue from anthocyanins and making them unstable (Mateo \& Di Stefano, 1997; Manzanares 

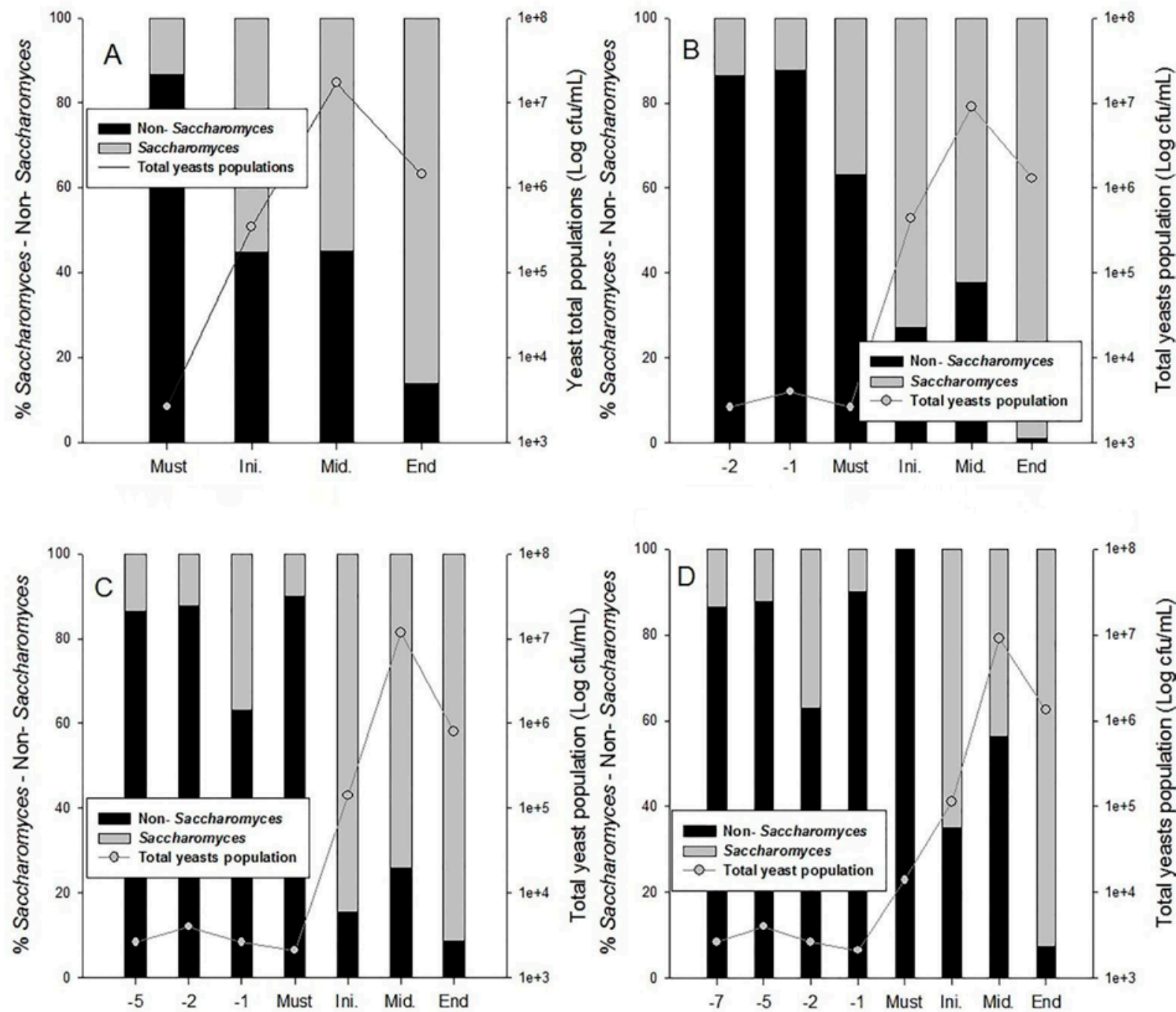

FIGURE 5

Proportion of Saccharomyces, non-Saccharomyces and total yeast population dynamics during cold soak (CS) and alcoholic fermentation (AF). Ini.: Initial AF, Med.: Middle AF, End: End AF. A: Control Treatment, B: Treatment 1, C: Treatment 2, D:

Treatment 3 .

et al., 2000; Vernocchi et al., 2015). Nevertheless, Boulton (2001) says the $\beta$-glycosidase is inactive when the glucose concentration is high.

During AF, two different behaviours related to anthocyanin were registered (Fig. 2). The first was described in the control treatment (CT) and Treatment 1 (T1), which extracted the highest amounts of TA until the middle of alcoholic fermentation (AF). In the CT, this fact could be explained by the similar proportions of Saccharomyces and non-Saccharomyces yeast populations during AF. It has been reported that non-Saccharomyces yeasts secrete polysaccharide-degrading enzymes (Strauss et al., 2001; Maturano et al., 2012), probably influencing grape cell-wall degradation and enhancing polyphenol extraction. After the middle of alcoholic fermentation, the loss of TA by CT and T1 could be attributed to several factors, for example adsorption to solids like (i) grape skins; in a classical vinification only $33.3 \%$ of the polyphenols are extracted (Vila, 2009), and the competition between anthocyanins and tannins should be taken into consideration (Bautista-Ortín et al., 2016), (ii) yeast cell walls $(\sim 10 \%)$ (Bautista-Ortín et al., 2016; Morata et al., 2016) and (iii) bitartrate crystals (Vila, 2009). It could be inferred that the yeast cell walls are the main factor due to the large size of the yeast populations at this point.

On the other hand, different behaviour was described in T2 and T3, where the loss of TA after the middle of AF was not observed. These findings are in contrast to those reported by Amrani Joutei and Glories (1984) and Ribéreau-Gayon et al. (2006), who describe the saturation or even loss of TA extraction in late AF. This behaviour - of not decreasing TA - could be explained by a possibly higher copigmentation phenomenon of these treatments induced during CS due to facilitated anthocyanin extraction and the availability of copigments (Mazza \& Brouillard, 1987; Cavalcanti et al., 2011; Casassa et al., 2015). Copigmentation possibly would have protected the anthocyanins from enzyme degradation (Mazza \& Brouillard, 1987; Boulton, 2001; Hermosín Gutiérrez, 2003; Jackson, 2014), but it mainly would have prevented the adsorption of anthocyanins to the yeast cell walls (Boulton, 2001). 
In relation to tannins (Fig. 3), T1, T2 and T3 registered an initial loss during the CS period. This could be related to hydro-soluble skin grape tannins released during this period. These have a large $\mathrm{mPD}$ (medium polymerisation degree), and could undergo precipitation (Vila et al., 2009). Later, an increase in tannins was registered in T3 at the end of CS. This is probably related to the increase in total yeast populations, mainly non-Saccharomyces, which could release polysaccharide-degrading enzymes of the cell wall, thereby increasing the release of polyphenols (Strauss et al., 2001; Maturano et al. 2012). These could also be atypical data, since tannins decay abruptly at the beginning of AF.

At the beginning of AF, the higher extraction of tannins probably was related to skin tannins. According to MorelSalmi et al. (2006), condensed tannins are major phenols and the main polymeric compounds. The subsequent lower extraction is probably related to seed tannins, which need ethanol to ensure dilution and extraction (Vila et al., 2009). Nevertheless, the CT, just as T3, did not follow typical curves (Vila et al. 2009) and seemed to describe the previous state to stabilisation.

The total polyphenol index (TPI) is mostly dependent on the concentration of anthocyanins and tannins. The results showed that an increase in time of CS at the assay temperature $\left(4^{\circ} \mathrm{C}\right)$ could increase the total polyphenol extraction in this period (Fig. 1). Similar results were obtained by Casassa (2007), who applied CS (seven days at $4^{\circ} \mathrm{C}$ ) to Malbec grapes and reported similar TPI values during this period. CT, T1 and T2 described typical extraction rates (Ribéreau-Gayon, 1982; Vila et al., 2009) and, after AF, all treatments had a TPI of higher than 55, which is high enough to be considered as premium wines (Zoecklein et al., 1995; Nazrala et al., 2009). However, the TPI trend at the end of AF in T3, where the extraction rate did not decrease, was unlike that reported by Ribéreau-Gayon (1982) and Vila et al. (2009). As mentioned above, this fact could be attributed to an increase in TA and tannins during the same period in $\mathrm{T} 3$.

At the end of AF, the highest polymerization index (PI) value was reached in $\mathrm{CT}$, and this is in logical concordance with the highest total polyphenol index value reached by this treatment, which is in agreement with the behaviour described by Glories (1984) and Escribano-Bailón et al. (2001) (Fig. 4). The opposite happened with PI in T3, which had low PI and low TPI. Also, the higher PI of the Control and lower PI of Treatment 3 could be related to the total yeast population achieved and the minor populations at the end of AF, as a result of the cell death registered in each treatment. During fermentation and after the yeasts die, the cells undergo autolysis, releasing mannoproteins from the cell wall (Morata et al., 2003; Alexandre \& GuillouxBenatier, 2006), specially some non-Saccharomyces yeast species (Giovani et al., 2012; Suárez-Lepe \& Morata, 2012). In this way, the polymerisations between anthocyanins and tannins could have been enhanced in CT but not in Treatment 3 (Chalier et al., 2007; Domizio et al., 2014).

Despite of the low values of TA registered compared with the rest of treatments, what is outstanding is that $\mathrm{T} 3$ registered the highest colour index (CI) in the present work. This could be explained by the colour intensification of copigmented anthocyanins (30\% to $50 \%$ colour intensification of a young wine) (Boulton, 2001; Baiano et al., 2015), which possibly occurred due to the larger CS time of this treatment. The different behaviour reported by T3 supports the hypothesis of a copigmentation: this treatment never showed a decrease in anthocyanin extraction; in contrast, it increased slightly and continuously because it did not suffer anthocyanin degradation or adsorption to the cell wall (Boulton, 2001).

In spite of D254 yeast inoculation in all treatments at the beginning of AF, Saccharomyces was found in low proportions until the end of AF in CT and T3 (Fig. 5A to D). On the other hand, Saccharomyces dominated the AF medium in $\mathrm{T} 1$ and $\mathrm{T} 2$ and cryotolerant strains were recorded (Fig. 5B and C). With the exception of the CT, this data could be related to the contribution of cryotolerant strains of native Saccharomyces populations, which are probably better adapted to grape must (Barrajón et al., 2011).

The chemical analysis revealed a normal to low content of glycerol (6.28 to $8.01 \mathrm{~g} / \mathrm{L}$ ) (Table 1) (Ribéreau-Gayon, 2006). Liu et al. (2016) reported $8.83 \pm 0.5 \mathrm{~g} / \mathrm{L}$ of glycerol in Cabernet Sauvignons wines from China. Titratable acidity $(6.46$ to $7.02 \mathrm{~g} / \mathrm{L})$, volatile acidity $(0.25$ to $0.33 \mathrm{~g} / \mathrm{L})$ and $\mathrm{pH}$ (3.86 to 3.89) were according to normal winemaking parameters (Ribéreau-Gayon, 2006). In the case of titratable acidity, the difference between $\mathrm{CT}$ and $\mathrm{T} 1$, and $\mathrm{T} 2$ and $\mathrm{T} 3$ could be explained by the time extension of maceration and the contact of the must with the grapes, where the liberation of potassium could precipitate tartaric acid (Reynolds et al., 2001; Casassa, 2007). Regarding volatile acidity there were significant differences between the control and the CS treatments, with the latter being higher. This result is in contrast with that obtained by Ortega-Heras et al. (2012), and studies have shown that some non-Saccharomyces yeasts even can produce less volatile acidity than Saccharomyces ones (Domizio et al., 2011). Also, yeasts fermenting wines at low temperature obtain less volatile acidity and less acetic acid (Beltran et al., 2008). Nevertheless, the presence of oxygen in fermentation absence could have benefited the temporal development of acetic acid bacteria. With reference to $\mathrm{pH}$, Alañón et al. (2016) reported similar values in Brazilian Cabernet Sauvignons wines, with a $\mathrm{pH}$ of $3.87 \pm 0.02$. On the other hand, Liu et al. (2016) reported a pH of $3.25 \pm 0.06$ in Chinese wines. As far as the dry extract is concerned, a high content of $\sim 25$ to $30 \mathrm{~g} / \mathrm{L}$ is considered positive (RibéreauGayon, 2006). These wines were outstanding, with values ranging between $36 \pm 1.83$ and $46.09 \pm 1.75 \mathrm{~g} / \mathrm{L}$. T2 and T3 had significantly different higher residual sugars than $\mathrm{CT}$ and T1. This could have been influenced by the longer duration of the maceration and the enhanced time when nonSaccharomyces yeasts with higher $\beta$-glycosidase activity were present in the must. This probably cleaved glucose from cellulose and increased the residual sugars, which perform in the same alcohol concentration. The results of this work are in agreement with those of Casassa et al. (2015), who obtained Cabernet Sauvignon wines with greater colour intensity (directly influencing the colour index) by applying cold soaking rather than traditional maceration.

\section{CONCLUSIONS}

Therefore, in agreement with the results reported above, it can be concluded that applying cold soak when making 
Cabernet Sauvignon wines is negative for wines that are to be aged due to the small amount of molecules such as anthocyanins and tannins extracted, which results in stable pigments. Nevertheless, it is promising for young wines in which a high colour index is required. We also can conclude that the microbiological aspect and its research is of major importance to take into account when colour aspects are researched. Furthermore, non- Saccharomyces yeasts are promising for obtaining better colour characteristics.

\section{LITERATURE CITED}

Alañón, M.E., Schumacher, R., Díaz-Maroto, M.C., Hermosín-Gutiérrez, I., Bettoni, J.C., Gardin, J.P. \& Pérez-Coello, M.S., 2016. By-products of pyro-bituminous shale as amendments in Brazilian vineyards: Influence on polyphenolic composition of Cabernet Sauvignon wines. Food Res. Int. 81, $122-132$.

Albertin, W., Miot-Sertier, C., Bely, M., Marullo, P., Coulon, J., Moine, V., Colonna-Ceccaldi, B. \& Masneuf-Pomarede, I., 2014. Oenological prefermentation practices strongly impact yeast population dynamics and alcoholic fermentation kinetics in Chardonnay grape must. Int. J. Food Microbiol. 178, 87-97.

Alexandre, H. \& Guilloux-Benatier, M., 2006. Yeast autolysis in sparkling wine - A review. Aus. J. Grape Wine Res. 12, 119-127.

Álvarez, I., Aleixandre, J.L., García, M.J. \& Lizama, V., 2006. Impact of prefermentative maceration on the phenolic and volatile compounds in Monastrell red wines. Anal. Chim. Acta 563(1), 109-115.

Amrani Joutei, K. \& Glories, Y., 1994. Etude en conditions modèles de l'extractibillté des composés phénoliques des pellicules et des pépins de raisins rouges. J. Int. Sci. Vigne et du Vin. 28(4), 303-317.

Asenstorfer, R.E., Markides, A.J., Iland, P.G. \& Jones, G.P., 2003. Formation of vitisin A during red wine fermentation and maturation. Aus. J. Grape Wine Res. 9, 40-46.

Baiano, A., Scrocco, C., Sepielli, G. \& Del Nobile, M.A., 2015. Wine processing: A critical review of physical, chemical, and sensory implications of innovative vinification procedures. Crit. Rev. Food Sci. Nutr. 56(14), 2391-2407.

Barrajón, N., Arévalo-Villena, M., Úbeda, J. \& Briones, A., 2011. Enological properties in wild and commercial Saccharomyces cerevisiae yeasts: Relationship with competition during alcoholic fermentation. World J. Microbiol. Biotechnol. 27(11), 2703-2710.

Bautista-Ortín, A. B., Martínez-Hernández, A., Ruiz-García, Y., Gil-Muñoz, R. \& Gómez-Plaza, E. 2016. Anthocyanins influence tannin-cell wall interactions. Food Chem. 206, 239-248.

Beltran, G., Novo, M., Guillamón, J.M., Mas, A. \& Rozès, N., 2008 Effect of fermentation temperature and culture media on the yeast lipid composition and wine volatile compounds. Int. J. Food Microbiol. 121(2), 169-177.

Benito, Á., Calderón, F. \& Benito, S., 2017. The combined use of Schizosaccharomyces pombe and Lachancea thermotolerans - Effect on the anthocyanin wine composition. Molecules 22(5), 739.

Boulton, R., 2001. The copigmentation of anthocyanins and its role in the colour of red wine: A critical review. Am. J. Enol. Vitic. 52:67-87.

Brouillard, R., 1982. Chemical structure of anthocyanins. Academic Press, New York.

Cadot, Y., Chevalier, M., \& Barbeau, G., 2011. Evolution of the localisation and composition of phenolics in grape skin between veraison and maturity in relation to water availability and some climatic conditions. J. Sci. Food Agric. 91(11), 1963-1976.
Casassa, L.F., 2007. Efecto de dos variantes de maceración prefermentativa en frio (MPF) sobre la composición y características organolépticas de vinos Malbec. Thesis, Universidad Nacional de Cuyo, .

Casassa, L.F., Bolcato, E.A. \& Sari, S.E., 2015. Chemical, chromatic, and sensory attributes of 6 red wines produced with prefermentative cold soak. Food Chem. 174, 110-118.

Casassa, L.F., Sari, S., Avagnina, S., Días, M., Jofré, V., Fanzone, M. \& Catania, C., 2007. Influencia de dos técnicas de maceración sobre la composición polifenolica, aromática y las características organolépticas de vinos cv. Merlot. Viticultura \& Enología Profesional, Mendoza, Argentina. $109,5-20$.

Cavalcanti, R.N., Santos, D.T. \& Meireles, M.A.A., 2011. Non-thermal stabilization mechanisms of anthocyanins in model and food systems - An overview. Food Res. Int. 44, 499-509.

Chalier, P., Angot, B., Delteil, D., Doco, T. \& Gunata, Z., 2007. Interactions between aroma compounds and whole mannoprotein isolated from Saccharomyces cerevisiae strains. Food Chem. 100(1), 22-30.

Charoenchai, C., Fleet, G., Henschke, P. \& Todd, B., 1997. Screening of non-Saccharomyces wine yeasts for the presence of extracellular hydrolytic enzymes. Aus. J. Grape Wine Res. 3, 2-8.

Cheynier, V., Dueñas-Paton, M., Salas, E., Maury, C., Souquet, J.M., Sarni-Manchado, P. \& Fulcrand, H., 2006. Structure and properties of wine pigments and tannins. Am. J. Enol. Vitic. 57(3), 298-305.

De Beer, D., Joubert, E., Marais, J. \& Manley, M., 2006. Maceration before and during fermentation: Effect on Pinotage wine phenolic composition, total antioxidant capacity and objective colour parameters. S. Afr. J. Enol. Vitic. 27(2), 137-150

Domizio, P., Liu, Y., Bisson, L.F. \& Barile, D., 2014. Use of nonSaccharomyces wine yeasts as novel sources of mannoproteins in wine. Food Microbiol. 43, 5-15.

Domizio, P., Romani, C., Lencioni, L., Comitini, F., Gobbi, M., Mannazzu, I. \& Ciani, M., 2011. Outlining a future for non-Saccharomyces yeasts: Selection of putative spoilage wine strains to be used in association with Saccharomyces cerevisiae for grape juice fermentation. Int. J. Food Microbiol. 147(3), 170-180.

Eglinton, J., Griesser, M., Henschke, P., Kwiatkowski, M., Parker, M. \& Herderich, M., 2004. Yeast-mediated formation of pigmented polymers in red wine. In: Anonymous (ed). ACS symposium series. Oxford University Press, pp. $7-21$

Escribano-Bailón, T., Álvarez-García, M., Rivas-Gonzalo, J.C., Heredia, F.J. \& Santos-Buelga, C., 2001. Colour and stability of pigments derived from the acetaldehyde-mediated condensation between malvidin 3-O-glucoside and (+)-catechin. J. Agric. Food Chem. 49(3), 1213-1217.

Fernández, M., Ubeda, J.F. \& Briones, A.I., 2000. Typing of nonSaccharomyces yeasts with enzymatic activities of interest in wine-making. Int. J. Food Microbiol. 59(1), 29-36.

Fleet, G.H., 2003. Yeast interactions and wine flavour. Int. J. Food Microbiol. 86, 11-22.

Fowell, R., 1965. The identification of wild yeast colonies on lysine agar. J. Appl. Bacteriol. 28, 373-383.

Fugelsang, K.C. \& Edwards C.G., 2006. Wine microbiology: Practical applications and procedures. Springer Science \& Business Media, New York. USA.

Giovani, G., Rosi, I. \& Bertuccioli, M., 2012. Quantification and characterization of cell wall polysaccharides released by non-Saccharomyces yeast strains during alcoholic fermentation. Int. J. Food Microbiol. 160(2), 113-118. 
Glories, Y., 1984. La couleur des vins rouges: 2e. Partie: mesure, origine et interpretation. Connaissance de la Vigne et du Vin. Bordeaux, France.

Gómez-Míguez, M., González-Miret, M.L. \& Heredia, F.J., 2007. Evolution of colour and anthocyanin composition of Syrah wines elaborated with prefermentative cold maceration. J. Food Eng. 79(1), 271-278.

González-Neves, G., Gil, G., Favre, G. \& Ferrer, M., 2012. Influence of grape composition and winemaking on the anthocyanin composition of red wines of Tannat. Int. J. Food Sci. Technol. 47(5), 900-909.

Gonzalez-San José, M.L., Santa-Maria, G. \& Diez, C., 1990. Anthocyanins as parameters for differentiating wines by grape variety, wine-growing region, and wine-making methods. J. Food Compos. Anal. 3(1), 54-66.

Granchi, L., Ganucci, D., Messini, A. \& Vincenzini, M., 2002. Oenological properties of Hanseniaspora osmophila and Kloeckera corticis from wines produced by spontaneous fermentations of normal and dried grapes. FEMS Yeast Res. 2(3), 403-407.

Heredia, F.J., Escudero-Gilete, M.L., Hernanz, D., Gordillo, B., MeléndezMartínez, A.J., Vicario, I.M. \& González-Miret, M.L., 2010. Influence of the refrigeration technique on the colour and phenolic composition of Syrah red wines obtained by pre-fermentative cold maceration. Food Chem. $118(2), 377-383$

Hermosín Gutiérrez, I., 2003. Influence of ethanol content on the extent of copigmentation in a Cencibel young red wine. J. Agric. Food Chem. 51, 4079-4083.

Hierro, N., González, Á., Mas, A. \& Guillamón, J.M., 2006. Diversity and evolution of non-Saccharomyces yeast populations during wine fermentation: Effect of grape ripeness and cold maceration. FEMS Yeast Res. 6(1), 102-111.

Iland, P., Bruer, N., Edwards, G., Weeks, S. \& Wilkes, E.. 2004. Chemical analysis of grapes and wine: Techniques and concepts. Patrick Iland Wine Promotions, Campbelltown.

Instituto Nacional de Vitivinicultura (I.N.V.)., n.d. Informe de Tolerancias Analíticas. www.inv.gov.ar/inv_contenidos/pdf/fiscalizacion/ ToleranciasAnaliticas-ResolucionesReglamentarias.pdf

Jackson, R.S., 2014 ( $4^{\text {th }}$ ed). Wine science. Food Science and Technology. Academic Press, Elsevier, London, UK. pp. 347 - 426.

Kammerer, D.R. 2016. Handbook on natural pigments in food and beverages. Elsevier, Amsterdam.

Kennedy, J.A., Ferrier, J., Harbertson, J.F. \& Des Gachons, C.P., 2006. Analysis of tannins in red wine using multiple methods: Correlation with perceived astringency. Am. J. Enol. Vitic. 57(4), 481-485

Kurtzman, C., Fell, J.W. \& Boekhout T. (eds)., 2011. The yeasts: A taxonomic study. Elsevier, London, UK.

Liu, G.L., Chi, Z., Wang, G.Y., Wang, Z.P., Li, Y. \& Chi, Z.M., 2013. Yeast killer toxins, molecular mechanisms of their action and their applications. Crit. Rev. Biotechnol. 35(2), 222-234.

Liu, P.T., Lu, L., Duan, C.Q. \& Yan, G.L., 2016. The contribution of indigenous non-Saccharomyces wine yeast to improved aromatic quality of Cabernet Sauvignon wines by spontaneous fermentation. LWT-Food Sci. Technol. 71, 356-363.

Mangani, S., Buscioni, G., Collina, L., Bocci, E. \& Vincenzini, M., 2011. Effects of microbial populations on anthocyanin profile of Sangiovese wines produced in Tuscany, Italy. Am. J. Enol. Vitic. 62, 487-494.

Manzanares, P., Rojas, V., Genovés, S. \& Vallés, S., 2000. A preliminary search for anthocyanin- $\beta$ - D- glucosidase activity in non-Saccharomyces wine yeasts. Int. J. Food Sci. Technol. 35(1), 95-103.

Marais, J., 2003. Effect of different wine-making techniques on the composition and quality of Pinotage wine - I: Low-temperature skin contact prior to fermentation. S. Afr. J. Enol. Vitic. 24, 70-75.
Mateo, J. \& Di Stefano, R., 1997. Description of the $\beta$-glucosidase activity of wine yeasts. Food Microbiol. 14, 583-591.

Maturano, Y.P., Assaf, L.A.R., Toro, M.E., Nally, M.C., Vallejo, M., Castellanos de Figueroa, L.I., Combina, M. \& Vazquez, F., 2012. Multienzyme production by pure and mixed cultures of Saccharomyces and nonSaccharomyces yeasts during wine fermentation. Int. J. Food Microbiol. 155(1), 43-50

Maturano, Y.P., Mestre, M.V., Esteve-Zarzoso, B., Nally, M.C., Lerena, M.C., Toro, M.E., Vazquez, F. \& Combina, M., 2015. Yeast population dynamics during prefermentative cold soak of Cabernet Sauvignon and Malbec wines. Int. J. Food Microbiol. 199, 23-32.

Mazza, G. \& Brouillard, R., 1987. Recent developments in the stabilization of anthocyanins in food products. Food Chem. 25, 207-225.

Mendoza, L.M., Manca de Nadra, M.C. \& Farías, M.E., 2007. Kinetics and metabolic behavior of a composite culture of Kloeckera apiculata and Saccharomyces cerevisiae wine related strains. Biotechnol. Lett. 29(7), 1057-1063.

Mendoza, L.M., Manca de Nadra, M.C., Bru, E. \& Farías, M.E., 2009. Influence of wine-related physicochemical factors on the growth and metabolism of non-Saccharomyces and Saccharomyces yeasts in mixed culture. J. Ind. Microbiol. Biotechnol. 36(2), 229-237.

Miller, G.L., 1959. Use of dinitrosalicylic acid reagent for determination of reducing sugar. Anal. Chem. 31(3), 426-428.

Morata, A., Gómez-Cordovés, M.C., Suberviola, J., Bartolomé, B., Colomo, B. \& Suárez, J.A., 2003. Adsorption of anthocyanins by yeast cell walls during the fermentation of red wines. J. Agric. Food Chem. 51(14), 4084 4088 .

Morata, A., Loira, I., Heras, J.M., Callejo, M.J., Tesfaye, W., González, C. \& Suárez-Lepe, J.A., 2016. Yeast influence on the formation of stable pigments in red winemaking. Food Chem. 197, 686-691.

Morel-Salmi, C., Souquet, J.M., Bes, M. \& Cheynier, V., 2006. Effect of flash release treatment on phenolic extraction and wine composition. J. Agric Food Chem. 54(12), 4270-4276.

Mortimer, R.K., 2000. Evolution and variation of the yeast Saccharomyces genome. J. Genome Res. 10, 403-409.

Nazrala, J.J.B., Paladino, S.C., Vila, H.F. \& Lucero, C.C., 2009. Manual de técnicas analíticas para mostos y vinos. Instituto Nacional de Tecnología Agropecuaria. Mendoza, Argentina.

Ortega-Heras, M., Pérez-Magariño, S. \& González-Sanjosé, M.L., 2012. Comparative study of the use of maceration enzymes and cold prefermentative maceration on phenolic and anthocyanic composition and colour of a Mencía red wine. LWT-Food Sci. Technol. 48(1), 1-8.

O.I.V., 1990. Recueil des méthodes internationales d'analyse des vins et des moûts. O.I.V., Paris.

Pelsy, F., 2010. Molecular and cellular mechanisms of diversity within grapevine varieties. Heredity 104(4), 331-340.

Reynolds, A., Cliff, M., Girard, B. \& Kopp, T.G., 2001. Influence of fermentation temperature on composition and sensory properties of Semillon and Shiraz wines. Am. J. Enol. Vitic. 52(3), 235-240.

Ribéreau-Gayon, P., 1982. The anthocyanins of grapes and wines. Academic Press, New York.

Ribéreau-Gayon, P., 1998. Traité d'OEnologie. 2-Chimie du vin. Stabilisation et traitements. Ed. La Vigne, Paris.

Ribéreau-Gayon, P., Glories, Y., Maujean, A. \& Dubourdieu, D., 2006 $\left(2^{\text {nd }} \mathrm{ed}\right)$. Handbook of enology: The chemistry of wine stabilization and treatments, Volume 2. John Wiley \& Sons Ltd. England. UK. 
Robinson J., 2006 ( $3^{\text {rd }}$ ed). The Oxford companion to wine. Oxford University Press

Somers, T.C. \& Evans, M.E., 1974. Wine quality: Correlations with colour density and anthocyanin equilibria in a group of young red wines. J. Sci. Food Agric 25, 1369-1379.

Somers, T.C. \& Evans, M.E., 1977. Spectral evaluation of young red wines: Anthocyanin equilibria, total phenolics, free and molecular $\mathrm{SO}_{2}$, "chemical age”. J. Sci. Food Agric. 28, 279-287.

Strauss, M.L.A., Jolly, N.P., Lambrechts, M.G. \& Van Rensburg, P., 2001 Screening for the production of extracellular hydrolytic enzymes by nonSaccharomyces wine yeasts. J. Appl. Microbiol. 91(1), 182-190.

Suárez-Lepe, J.A. \& Morata, A., 2012. New trends in yeast selection for winemaking. Trends Food Sci. \& Tech. 23(1), 39-50.

Sudraud, P., 1958. Interpretation des courbes d'absorption des vins rouges. Ann. Technol. Agric. 7(2), 203-208.
Vernocchi, P., Patrignani, F., Ndagijimana, M., Lopez, C.C., Suzzi, G., Gardini, F. \& Lanciotti, R., 2015. Trebbiano wine produced by using Saccharomyces cerevisiae strains endowed with $\beta$-glucosidase activity. Ann. Microbiol. 65(3), 1565-1571.

Vila, H.F., Paladino, S.C., Nazrala, J.J.B. \& Lucero, C.C., 2009. Manual de técnicas analíticas para la evaluación de compuestos fenólicos y otros componentes de la uva. Instituto Nacional de Tecnología Agropecuaria. Mendoza. Argentina.

Zoecklein, B.W., Gump, B., Fugelsang, K. \& Nury, F.S., 1995. Wine analysis and production. Chapman and Hall, New York.

Zou, H., Kilmartin, P.A., Inglis, M.J. \& Frost, A., 2002. Extraction of phenolic compounds during vinification of Pinot Noir wine examined by HPLC and cyclic voltammetry. Aust. J. Grape Wine R. 8(3), 163-174. 